\title{
Development of Science E-module Based on SETS (Science, Environment, Technology, and Society) with Formative Assessments to Improve Critical Thinking Ability of Grade IX Students on Biotechnology Materials
}

\author{
Dwi T. Arianti ${ }^{1}$ Parno Parno ${ }^{2, *}$ Muhammad F. Marsuki ${ }^{1}$ Isnanik J. Fitriyah ${ }^{1,}$
}

Safwatun Nida ${ }^{1}$

${ }^{1}$ Department of Science Education, Universitas Negeri Malang

${ }^{2}$ Department of Physics, Universitas Negeri Malang

*Corresponding author.Email:parno.fmipa@um.ac.id

\begin{abstract}
Biotechnology is essential to learn, but students still have difficulty learning due to a low understanding of learning materials, and students are not directly involved in learning, so that it hampers students' ability to think critically. However, the development of SETS-based teaching materials with formative assessments in junior high school biotechnology learning as an effort to improve critical thinking skills is still rarely done. The purpose of this study was to develop and test the feasibility of a SETS-based biotechnology e-module with formative assessment in improving the critical thinking skills of grade IX junior high school students. The research procedure used is a modification of the 4-D model. The research instruments used were material validation questionnaires, media validation questionnaires, and readability test questionnaires. The validation results show fea sibility percentage of the e-module is $88.93 \%$ with a very feasible category. The percentage of e-module readability was $92.01 \%$ with a very good category. Thus, an e-module based is included in the very feasible category so that it can be applied to improve students' critical thinking skills in biotechnology materials. For further research, this product development is recommended to be tested for effectiveness and implemented in classroom learning.
\end{abstract}

Keywords: Biotechnology, Critical Thinking, E-module, SETS.

\section{INTRODUCTION}

Biotechnology is a crucial learning material to learn to prepare students to be able to innovate in the future. Biotechnology is the application of bioscience and technology related to the practical use of living organisms and their subcellular components in environmental management, services, and manufacturings [1]. The condition of Indonesia's population, which is projected in 2035 will increase, impacting the need for water and food sources, greenhouse gas emissions, and climate change. Biotechnology is expected to overcome these problems [2]. Biotechnology is considered difficult because many of the basic concepts are abstract [3], low concept understanding [4], and the material is only delivered through the lecture method so that students are less active in learning [5]. In addition, based on research by Zetkas, et al. (2016), 54.38\% of the results of studying biotechnology materials for grade IX junior high schools in Padang Sidempuan city scored below the KKM [4]. The cause of low learning outcomes can be due to the low understanding of students on learning materials and students are not directly involved in learning so that it hampers students' ability to think critically [6]. Students' critical thinking ability in Indonesia is low by supported OECD publication data in 2012, which showed that Indonesia obtained an average score of 383 and was ranked 64th out of 65 OECD member countries [7]. 
Training students to think critically is essential because students are trained to see the situation, raise questions, describe hypotheses, conduct investigations, collect data, and draw conclusions from what is observed [8]. So it takes efforts to improve critical thinking skills in biotechnology materials.

Several studies on biotechnology materials for grade IX have been conducted, but they are still focused on improving learning outcomes. The research is: Multimedia Tutorial to Improve Learning Outcomes [7], The Influence of Investigation Group Type Cooperative Learning Model and Learning Creativity on Biotechnology Learning Outcomes [10], Improving Student Cognitive Learning Outcomes and Teacher Activities Through Problem Based Learning Models [11], Development of Community Science Technology Oriented Biology Learning Modules Accompanied by Concept Maps [3], and The Effect of Project-Based Learning Model on Critical Thinking Skills, Activities and Science Learning Outcomes [10]. The research also shows that solutions to overcome the low critical thinking skills of grade IX junior high school biotechnology materials are still rare, some studies have not a ccommodated the abstract characteristics of biotechnology materials, and do not relate science and technology to everyday life.

Learning that does not relate science and technology to everyday life can be overcome with the SETS approach because it combines science and its involvement in technology, environment, society and is connected to real life [13]. Research on SETS learning has been conducted, but research on SETS learning on biotechnology materials for junior high school is still rare. The research is: the Development of an Integrated Science Module Based on SETS on the Theme of Food and Body Health [14], Development of Integrated Science Learning Devices with SETS Vision Based on Edutainment on the Digestive Theme [13], Learning Natural Disasters with SETS Visionary Pairs Exchange Model [16], and Development of Science Teaching Material Based Inquiry Integrated with SETS on Human Reproductive System Materials [15].

Critical thinking skills can be improved through SETS learning. Based on research by Asmuri, et al. (2019), the SETS approach to the module has an impact on increasing critical thinking skills as evidenced by an increase in student scores to 81.11 from 45.42 previously, with an $\mathrm{N}$-gain score of 0.6 [14]. Based on the research of Nisak, et al. (2017), the results of the LSD further test showed that there were significant differences in students' critical thinking skills using Guided Inquiry based on SETS learning compared to conventional learning [18]. Thus, students' critical thinking skills can be improved through SETS learning.

Presentation of abstract material can be assisted with e-modules because the presentation of e-modules is more dynamic, more interactive, and presents learning materials visually using video tutorials [19]. E-modules effectively improve critical thinking skills shown in the research of Nikita, et al. (2018), the a vera ge $\mathrm{N}$-gain score of critical thinking skills through tests in e-modules is 0.81 [20].

The results of research by several researchers in the development of e-modules for science learning in junior high schools are only e-modules not accompanied by formative assessments. However, several studies show the development of junior high school science e-modules with formative assessments, namely science e-modules containing online tests to improve learning outcomes, where e-modules integrate formative tests in the form of online tests [19]. At this time learning has not formed the habit of thinking, prioritizing the formation of knowledge, and tends to improve learning outcomes [22]. To form thinking habits trained by applying formative assessment [22]. Thus, the development of e-modules based on SETS needs to be accompanied by formative assessments to improve learning outcomes effectively. Based on these descriptions, the purpose of the research is to develop a biotechnology e-module based on SETS with formative assessment in improving the critical thinking skills of grade IX junior high school students.

\section{METHOD}

This research uses the $\mathrm{R} \& \mathrm{D}$ (Research and Development) method with a 3-D model(modification of the 4-D model), namely Define, Design, and Develop, which was carried out by Wahyuni (2015) in his research [8]. At the Define stage, the requirements needed to develop e-modules are determined based on the needs of grade IX biotechnology learning [8], conducted through library research. At the Design stage, the various components needed in the manufacture of e-modules are designed [8], conducted through the activities of making and compiling emodules, formative assessments, questionnaire instruments for validation of material, media, and readability test. The Develop stage, is carried out to determine the data on the feasibility level of the emodule being developed [8], conducted through product validation researchers by 1 lecturer and 1 
teacher who are both material experts and media experts and test the readability on students.

The research subjects were 33 students of grade IX at SMPN 23 Malang. Data collection techniques were carried out through the validation stage and rea dability test. The instruments are material expert validation questionnaire, media expert validation questionnaire, and readability test questionnaire. The assessment a spect of the validation questionnaire is an adaptation of the assessment component by National Education Standards Agency and Ministry of National Education. The aspect assessment of readability test questionnaire is made by researchers based on a literature study. In this study, an e-module was designed, validated, then tested for readability on students. The data research is then analyzed and the evaluation results are reported. The data in this research is qualitative data and quantitative data. Qualitative data were obtained from written suggestions from validators regarding the fea sibility of e-modules and students' comments and suggestions regarding the e-module readability test. Quantitative data is the result of validation assessments of media experts and material experts on e-modules using a Likert scale [23], and the e-module readability test questionnaire using the Guttman scale [23]. The data is analyzed using average value analysis technique to determine the validity [24] and assessment of emodule readability test [25]. The validity and readability test are assessed by giving a checklist in the options provided. The criteria questionnaire by Likert scale can be seen in Table 1 [23].

Table 1. Questionnaire assessment criteria

\begin{tabular}{|c|c|}
\hline Score & Information \\
\hline 4 & Very good \\
\hline 3 & Well \\
\hline 2 & Pretty good \\
\hline 1 & Less good \\
\hline
\end{tabular}

The criteria for readability test questionnaire by Guttman scale is with the description "Yes" (score 1) or "No" (score 0) [23]. The average value analysis technique formula is:

$$
P=\frac{\sum x}{\sum x_{i}} \times 100 \%
$$

Information:

$\mathrm{P}=$ Percentage of Fea sibility

$\sum x_{i}=$ maximum score

$\sum x=$ totalscore obtained [24]
The percentage of e-module fea sibility and e-module readability test criteria can be seen in Table 2 [26] and Table 3 [25].

Table 2. E-module fea sibility criteria

\begin{tabular}{|c|c|}
\hline Score (\%) & Information \\
\hline $\begin{array}{c}85,01- \\
100,00\end{array}$ & $\begin{array}{c}\text { Very decent, usable with minor } \\
\text { revision }\end{array}$ \\
\hline $70,01-85,00$ & Decent, usable with minor revision \\
\hline $50,01-70,00$ & $\begin{array}{c}\text { Less feasible, can be used with } \\
\text { major revisions }\end{array}$ \\
\hline $60,01-50,00$ & Not worth it, can't be used \\
\hline
\end{tabular}

Table 3. Rea dability test questionnaire criteria

\begin{tabular}{|c|c|}
\hline Score $(\%)$ & Information \\
\hline $75,01-100,00$ & Very good \\
\hline $50,01-75,00$ & Well \\
\hline $25,01-50,00$ & Pretty good \\
\hline $0,00-25,00$ & Not good \\
\hline
\end{tabular}

\section{RESULTS AND DISCUSSION}

This study develops a SETS-based e-module with a formative assessment of biotechnology materials. Emodule is a type of independent teaching material in learning that is made in electronic form and arranged systematically [27].



Figure 1 Front cover page

Figures 1 show the cover page of e-module. Each e-module page contains several buttons with their respective functions. E-module developed with software Flip PDF Professional. Flip PDF Professional is software for creating e-books in the form of flipbooks equipped with audio, video, and Flash animation [28]. The developed e-module contains an introduction, table of contents, list of pictures, glossary, concept map, introduction, MB 1 and MB 2 learning activities, answer keys \& scoring guidelines, and bibliography. The glossary section contains definitions of important concepts. The introduction section, KD, IPKD, learning objectives, descriptions, instructions for use, and activity 
components. Instructions for use serve as pointers to make it easier to understand the e-module. The activity component contains an explanation of the learning activities, namely MB 1 (biotechnology and its principles and types of biotechnology) and MB 2 (the application of biotechnology in life and the impact of biotechnology). The activity components consist of: Let's Get to Know the Problems in the Surrounding Environment, Let's Identify, Let's Formulate Solutions, Let's Apply Concepts, Let's Check Concept Knowledge, and Let's Test Knowledge. Activity component is adjusted to the critical thinking skills indicators according to Facione (2020) and formative assessment strategies.

The activity "Let's Get to Know the Problems in the Surrounding Environment" is in accordance with the invitation stage in SETS learning, which is to provide actual issues that are developing in the community [29][30][31], by presenting videos according to learning topic so that students understand and identify problems. This activity is in accordance with the scientific aspects of SETS learning, namely using scientific knowledge [32], to identify the problem. This activity can improve critical thinking skills according to interpretation indicators, namely the ability to understand and interpret a problem [33], which is indicated in the identification of problems of biotechnology. This activity is also appropriate with the formative assessment strategy KS1. Clarifying, sharing, and understanding learning intentions and the criteria for success [34], which is shown in identifying the problem in the video and students clarify (explain) the problem. In the MB 1 activity, the video presented contains issues or problems regarding the scarcity of red ginger because it has been sought after by the community since the Covid-19 virus. In the MB 2 activity, the video presented contains issues or problems regarding the increase in the price of red chili due to several factors. In this stage, students understand, identify and explain whether the problem is appropriate or not with the topic of biotechnology.

The "Let's Identify" activity is a ppropriate with the stage of concept formation in SETS learning, namely doing activities with various methods as a step in solving problems through the formation of concepts that are suitable for scientists and understanding whether the problem analysis presented is following the concepts of scientists [29][30][31]. Furthermore, students analyze and classify problems according to aspects of science, environment, technology, and society. This activity is in accordance with aspects of science, environment, technology, and society in SETS learning. The scientific aspect in question issues scientific knowledge and identifies questions [32] to identify problems expressed in interrogative sentences. The environmental aspects in question are to understand problems related to environmental systems [35]. Students identify whether the problems are related to the environment. The technological aspect in question is understanding suitable technology to overcome problems [36]. Aspects of society related to the environment and interactions between individuals [37], meaning that this activity is related to analyzing the impact of problems on the environment and society. This activity can improve critical thinking skills according to analysis and inference indicators. The analysis indicators in question are the ability to identify the descriptions and relationships of the various statements presented [33]. Indicator inference what is meant is the ability to identify and obtain various components needed in making conclusions [33]. This activity is appropriate with the formative assessment strategy KS2. Engineering effective classroom discussions, questions, and tasks that elicit evidence of learning [34], in question are to raise questions and obtain various components as evidence in determining conclusions. After understanding the problems, students will be directed to raise a question about the problems presented. In MB 1 activity is given an example of the question "Why is red ginger becoming rare?", while in the MB 2 activity, an example of the question is "Why did the price of chili increase?". Next, students made other questions about the topic so that a hypothesis was obtained. These questions are problems that students then group based on SETS learning aspects. This is done so that students better understand the problems in various sectors.

The "Let's Formulate Solution" activity is appropriate with the concept formation stage in SETS learning, is doing activities with various methods as a step in solving problems through the formation of concepts that are suitable for scientists and understanding whether the problem analysis presented is by the concepts of scientists [29][30][31], namely determining solutions to solve problems with biotechnological concept according to aspects of science, environment, technology, and society. Solutions are directed to refer to practicum activities according to the learning topic. This activity follows the aspects of science, environment, technology, and society in SETS learning which is shown in learning activities that encourage students to use scientific knowledge [32] to determine solutions, understand the impact of solutions on the environment [35], rea soning the appropriate technology as a form of solution [36], and rea soning about its impact on life and interactions in society [37]. This activity can improve critical 
thinking skills according to analysis and inference indicators. The analysis indicators in question are the ability to investigate ideas [33], in determining a solution. Indicator inference is the ability to draw conclusions and predict an alternative [33], as a form of solution. This activity is also by the formative assessment strategy KS2. Engineering effective classroom discussions, questions, and tasks that elicit evidence of learning [34], namely engineering classroom learning in the form of practicum and obtain learning evidence in the form of conclusions that practicum can be used as solution to solve problems. In the MB 1 activity, students made a solution to the problem of red ginger scarcity, while in the MB 2 activity made a solution to the problem of rising chili prices by reasoning on various biotechnology concepts. Next, students are directed to do practicum activities, where the practicum refers to solutions to problems. In MB 1 activities, practicum activities were conducted about ginger plant tissue culture, while in MB 2 activities, practicum activities were about chili plants using the hydroponic wick system. The practicum uses biotechnology techniques that will provide solutions for propagation of red ginger and red chili plants. This activity is also equipped with practicum objectives, theoretical basis, and practicum steps which are presented both in the form of explanations and in videos. After that, students answer questions about the practicum and conclude whether the practicum carried out can be used as a solution to the problems presented. At this stage, students are expected to understand the correct handling of problems using the biotechnological concept by considering aspects of science, environment, technology, and society.

The "Let's Apply the Concept" activity is follows the concept application stage in SETS learning, namely issue analysis and applying the concepts obtained in finding the right solution [29][30][31]. The activity in question is that students are trained to determine solutions to problems regarding biotechnology in practice questions. This activity is in accordance with aspects of science, environment, technology, and society in SETS learning which is shown in learning activities that encourage students to use scientific knowledge [32] to determine solutions, understand the impact of solutions on the environment [35], reasoning the appropriate technology as a form of solution [36], and reasoning about its impact on their lives and interactions in society [37]. This activity can improve critical thinking skills according to analysis and explanation indicators. The analysis indicators in question are the ability to investigate ideas [33], in determining a solution. The indicator explanation in question is the ability to state and reason logically based on evidence and concepts [33], meaning that students are trained to convey their thoughts about solutions based on known proofs and concepts. This activity is in accordance with the formative assessment strategy KS2. Engineering effective classroom discussions, questions, and tasks that elicit evidence of learning [34], namely by doing practice questions to find solutions to the problems. After understanding the concept of biotechnology, students apply the biotechnology concept in solving problems through practice questions according to practicum topics. In MB 1 activity students analyze problems regarding tissue culture, while in MB 2 activities students a nalyze problems about hydroponic techniques. Then students answer and explain the answers to the questions. This activity also contains learning materials presented in the form of "About Biotechnology", as a learning reference presented in the form of explanations and learning videos.

The "Let's Check Concept Knowledge" activity is follows the concept stabilization stage in SETS learning, namely obtaining feedback or reinforcement from the concepts learned to ensure the truth of the concepts understood [29][30][31], through writing things that have not been understood about the learning topic as a form of feedback, then students are given practice questions to understand better and ensure the truth of the concept. To find out the truth of the concept can be done by observing the answers answered by students whether it has been suitable with theory. This activity is appropriate with the science aspect, in SETS learning, namely use scientific knowledge, identify questions, make conclusions based on evidence [32] to answer problems, identify questions and make conclusions in the form of answers to practice questions. This activity can improve critical thinking skills according to evaluation indicators, namely the ability to a ssess a sta tement or explanation and conclude questions, descriptions, concepts, and relationships from various statements logically [33], meaning that students are trained to assess the statements presented in the practice questions, then conclude the answers. This activity is follows the formative assessment strategy KS 3. Providing feedback that moves learners forward [34], in the form of things that students have not understood according to the learning topic.

Students increase knowledge through the "Let's Test Knowledge" activity which is follows the assessment stage in SETS learning, namely assessing students' abilities and knowledge after learning activities [29][30][31]. Students answer practice questions to assess their knowledge. This activity can 
improve critical thinking skills according to indicators self-regulation, that is the ability to monitor cognitive activity [33], which means monitoring the level of knowledge about biotechnology through doing practice questions. This activity is follows the aspects of science, environment, technology, and society in SETS learning which is shown in learning activities that encourage students to use scientific knowledge [32] to determine solutions, understand the impact of solutions on the environment [35], assess appropriate technology as a form of solution [36], and reasoning about its impact on their lives and interactions in society [37] in the practice questions. This activity is in accordance with the formative assessment strategy KS 4. Activating students as instructional resources for one another and KS 5. Activating students as the owners of their own learning [34] is shown in learning activities that encourage students to be more active in learning through practice questions and selfassessment according to each learning topic. The results of the e-module feasibility assessment are.

Table 4. E-module fea sibility assessment

\begin{tabular}{|c|c|c|c|}
\hline Aspects & Rated aspect & Score (\%) & Average \\
\hline \multirow{3}{*}{$\begin{array}{c}\text { Mate ria } \\
\text { I }\end{array}$} & Content Feasibility & $91.35 \%$ & \\
\cline { 2 - 3 } & Serving Feasibility & $87.5 \%$ & \multirow{2}{*}{$86.9 \%$} \\
\cline { 2 - 3 } & Language Feasibility & $81.94 \%$ & \\
\cline { 2 - 3 } & Contextual Assessment & $84.72 \%$ & \\
\hline Media & Graphic Feasibility & $91.96 \%$ & $91.96 \%$ \\
\hline
\end{tabular}

The average feasibility percentage is $88.93 \%$ with a very feasible category [26]. The material aspect contains aspects of content feasibility assessment, presentation feasibility, language feasibility, and contextual a ssessment. In a spect of content fea sibility, the average of each indicator, namely: conformity of material to $\mathrm{KD}$ is $95.83 \%$, materialaccuracy is $87.5 \%$, material update is $95.83 \%$, encouraging curiosity is $87.5 \%$. In a spect of presentation feasibility, the a verage of each indicator, namely: presentation technique is $81.25 \%$, presentation supporting is $93.75 \%$, learning presentation is $75 \%$, and coherence and traces of the flow of thought is $81.25 \%$. The indicators of presentation techniques and learning presentations get less maximum results than other assessment indicators. Based on presentation technique indicators, the presentation of material in e-modules must have a clear systematic, and coherent presentation of concepts ranging from easy to complex, from concrete to abstract. According to Daryanto and Dwicahyono in Desyandri, et al. (2019), one of the principles of developing teaching materials is that the presentation of teaching materials is do from easy to complex understanding, from concrete to abstract understanding, and high learning motivation [38]. Based on learning presentation indicators, the presentation of e-modules should make students more active in learning. This is in suitable with the guidelines for preparing e-modules by the Kemdikbud Team (2017) that e-modules are created to provide opportunities for students to be more active in learning and solve learning difficulties [19]. An aspect of language feasibility, the average on each indicator, namely: straightforward is $79.16 \%$, communicative is $87.5 \%$, dialogical and interactive is $87.5 \%$, conformity with the development of students is $75 \%$, and conformity to getting langua ge rules is $87.5 \%$. Straightforwardness and conformity with the development of students indicators, the results are less than optimalcompared to other a ssessment indicators. Based on straightforward indica tors, the e-module uses standard terms, effective sentences, and suitable sentence structures. One of the user-friendly characteristics of the module is that the information presented in it helps understanding information and is suitable to the reader, using language that is easy to understand, simple, and use many standard terms [25]. Based on conformity with the development of students indicators, e-modules must follow students' intellectual and emotional development. One of the principles of emodule development is that e-modules are arranged according to the needs and learning objectives that students want to achieve [39]. In the contextual assessment aspect, the average on each indicator is: contextual nature is $87.5 \%$, and contextual component is $83.9 \%$. Contextual component indicators get less than optimal results compared to other indicators. Based on contextual component indicators, e-modules must develop the ability to ask questions and find knowledge, including assignments, material summaries, sample questions, and tests to assess learning outcomes. This is following the guidelines for the preparation of e-modules by the Kemdikbud Team (2017) that e-module framework consists of a cover page, foreword, table of contents, glossary, introduction, learning activities (containing objectives, material descriptions, summaries, assignments, worksheets, practice questions, and self-assessment), evaluation (knowledge competency test \& skill competency), answer key \& scoring guidelines, bibliography, and attachments [19]. According to Kurniasih and Sani in Desyandri, et al. (2019), one of the principles of developing tea ching materials, na mely, teaching materials, must be able to generate students' curiosity (discover) and foster student activity [38]. In the media aspect, it contains aspects of the graphic feasibility assessment which consists of several indicators. The average on each indicator, namely: module size is $100 \%$, module cover design is $84.375 \%$, 
and module content design is $91.67 \%$. Cover design indicators get less than optimal results than other indicators. Based on module cover design indicators, the e-module must have a good, complete, harmonious, and consistent component layout that provides a good center of the view. According to Sugianto, et al. (2018), an attractive design and appearance as well as the selection of the right illustrations can make it easier for students to understand the material so that it will attract students' interest in learning [25]. There are suggestions for improvement from validator that is adding learning goals, IPKD, and scores to each answer key, e-modules are cleaned up and add videos and practice question. For videos and practice question is not added because it considers the time of learning activities. The improvements are presented in the figure 2 .

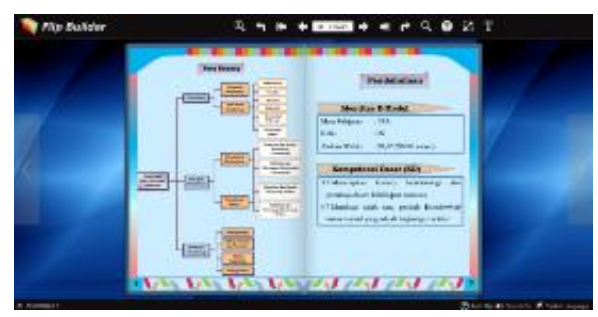

(a)

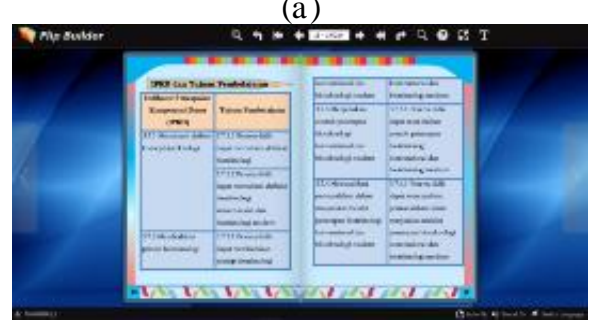

(b)

Figure 2 (a) Without IPKD and learning objectives, (b) With IPKD and learning objectives

Figures $2 \mathrm{a}$ and $2 \mathrm{~b}$ show the appearance of $\mathrm{e}$ module before and after adding the IPKD and learning objectives. In the media aspect, validator 1 gives advice "Continue to develop e-modules to help students understand the concept of material and shape student creativity in the digital era like today". Validator 2 gives advice "This E-Module is good if it is applied in learning, it only needs to consider the time to deepen each activity". So, it can be seen that the emodule is good. Improvements made were to increase the time for some learning activities. The results of emodule readability test is:
Table 5. E-module readibility assessment

\begin{tabular}{|c|c|}
\hline $\begin{array}{c}\text { Aspect of assessment } \\
\text { appropriate wording }\end{array}$ & Score \\
\hline $\begin{array}{c}\text { Ese simple sentences, not too long, and have } \\
\text { Use easy-to-understand sentences }\end{array}$ & $96.97 \%$ \\
\hline $\begin{array}{c}\text { Can attract interest and motivation to learn } \\
\text { module have a suitable layout }\end{array}$ & $96.97 \%$ \\
\hline $\begin{array}{c}\text { The symbols, icons, and images in the e- } \\
\text { do not dominate the e-module page }\end{array}$ & $90.91 \%$ \\
\hline $\begin{array}{c}\text { Contains biotechnology learning materials } \\
\text { that link science, environment, technology, } \\
\text { and society }\end{array}$ & $96.97 \%$ \\
\hline Interesting view & $96.73 \%$ \\
\hline Encourage curiosity to learn & $93.94 \%$ \\
\hline Aake learning more fun and not boring & $87.88 \%$ \\
\hline Can be used for independent study & $84.85 \%$ \\
\hline Average & $92.01 \%$ \\
\hline
\end{tabular}

The average percentage of readability test is $92.01 \%$ with a very good category [25]. On aspect "Symbols, icons, and images in the e-module do not dominate the e-module page" get less than optimal compared to other assessment aspects. Preferably, emodules use symbols that are not too many because can interfere with student concentration and can distract students from the learning material [25]. There are suggestions and opinions of student "e-module can encourage curiosity to learn", "background-color is too flashy, suitable to be used for additional teacher reference in learning". Improvements made are to change the background color of the e-module.

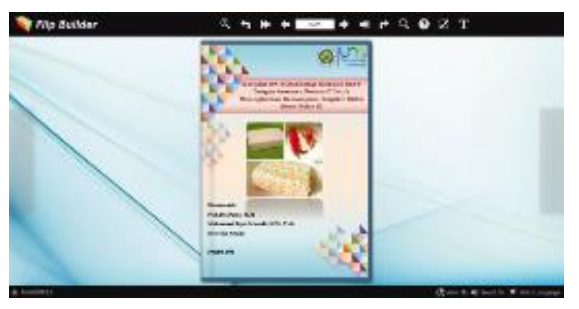

Figure 3 E-module background after repair

Based on the results, it can be concluded that emodule can be used as an opportunity to improve students' critical thinking skills in biotechnology materials. E-modules can help the presentation of abstract material [19], SETS integration helps students relate science and technology to everyday life and their involvement in the environment and society [13]. 
SETS learning can improve critical thinking skills [12][18]. E-modules need to be accompanied by formative assessments so that the learning not only improves learning outcomes but can form thinking habits [22], set learning strategies and steps for continuous learning [40].

\section{CONCLUSION}

Based on the results, it can be concluded that emodule fall into the very feasible category with an a vera ge feasibility percentage of $88.93 \%$. The average percentage of e-module readability test results is $92.01 \%$ with a very good category. Therefore, the emodule fall into very feasible so that it can be applied to improve the critical thinking skills of junior high school students on biotechnology material. For further research, this product development is recommended so that it can be tested for effectiveness and implemented in classroom learning.

\section{AUTHORS' CONTRIBUTIONS}

All authors conceived and designed this study. All authors contributed to the process of revising the manuscript, and at the end all authors have approved the finalversion of this manuscript.

\section{ACKNOWLEDGMENTS}

The author would like to thank the principal, science teachers, and students at SMPN 23 Malang who helped implement the research.

\section{REFERENCES}

[1] Sutarno, Rekayasa Genetik dan Perkembangan Bioteknologi di Bidang Peternakan, vol. 13, no. 1, Proceeding Biology Education Conference, 2016, pp. 23-

27.URL:https://jurnal.uns.ac.id/prosbi/article/viewFile $15642 / 5010$

[2] A. K. Wardani, S. D. Wijayanti, E. Widyastuti, Pengantar Bioteknologi, Universitas Brawijaya Press, 2017.

[3] S. Efdillah, L. Lufri, Y. Ahda, "Pengembangan Modul Pembelajaran Biologi Berorientasi Sains Teknologi Masyarakat Disertai Peta Konsep pada Materi Bioteknologi", Kolaboratif 1(2) (2013) 31-40. URL: http://ejournal.unp.ac.id/index.php/kolaboratif/article/ view/4929

[4] E. Zetkas, F. Harahap, S. Edi, "Analisis Pemahaman dan Kesulitan Belajar Siswa Materi Bioteknologi Berdasarkan Indikator Kelas IX SMP Se-Kota Padang Sidempuan", J. Pendidik. Biol. 5(3) (2016) 154-159. DOI: $10.24114 /$ jpb.v5i3.4314.

[5] M. C. Dewi, H. M. Zaini, H. Y. F. A. Arifin, "Pengembangan Perangkat Pembelajaran Konsep
Bioteknologi Menggunakan Model Pembelajaran Berdasarkan Masalah DI SMP", Landasan-Jurnal Ilm. Kependidikan Kemasyarakatan 9(1) (2014). URL: http://eprints.ulm.ac.id/453/2/5.\%20artike1\%20Maria $\% 20$ Yovita_docx.pdf

[6] E. T. Fatmawati, S. Sujatmika, "Efektivitas Pembelajaran Problem Based Learning Terhadap Hasil Belajar IPA Ditinjau Dari Kemampuan Berpikir Kritis", Wacana Akademika 2(2) (2018) 163. DOI: 10.30738/wa.v2i2.2786.

[7] R. Khasani, S. Ridho, B. Subali, "Identifikasi Kemampuan Berpikir Kritis Siswa SMP Pada Materi Hukum Newton", JPPIPA 5(2) (2019) 165-169. DOI: 10.29303/jppipa.v5i2.192

[8] S. Wahyuni, Pengembangan Bahan Ajar IPA untuk Meningkatkan Kemampuan Berpikir Kritis Siswa SMP, vol. 6, no. 1, Prosiding Seminar Nasional Fisika dan Pendidikan Fisika, 2015, pp. 300-305. URL: https://jurnal.fkip.uns.ac.id/index.php/prosfis 1/article/ view/7857

[9] M. Khoerunisa, D. Maknun, A. Mulyani, "Pembelajaran Bioteknologi Berbasis Multimedia Tutorial untuk Meningkatkan Hasil Belajar Siswa Kelas IX di SMPN 8 Kota Cirebon", Scientiae Educatia 3(2) (2014) 55-70. URL: https://core.ac.uk/download/pdf/270192372.pdf

[10] Zubaidi, R. Asyhar, Syamsurizal, "Pengaruh Model Pembelajaran Kooperatif Tipe Group Investigasi (GI)", Tekno-Pedagogi 3(1) (2013) 42-49. URL: https://online-

journal.unja.ac.id/pedagogi/article/view/2298

[11] D. K. Agustina, "Meningkatkan Hasil Belajar Kognitif Siswa dan Aktivitas Guru pada Materi Bioteknologi Pangan Kelas IX MTs Melalui Model Pembelajaran Berbasis Masalah", Konstruktivisme: Jurnal Pendidikan dan Pembelajaran 7(2) (2015) 107-118. DOI: https://doi.org/10.35457/konstruk.v7i2.15

[12] S. M. Syamsuddin, "Pengaruh Model Project Based Learning Terhadap Keterampilan Berpikir Kritis, Aktivitas Dan Hasil Belajar IPA Pada Materi Bioteknologi Peserta Didik Kelas IX.2 SMP Negeri 12 Parepare", Doctoral dissertation, Pascasarjana, 2019, 1-18. URL: http://eprints.unm.ac.id/12551/

[13] N. Khasanah, SETS sebagai Pendekatan Pembelajaran IPA Modern pada Kurikulum 2013, Seminar Nasional Konservasi dan Pemanfaatan Sumber Daya Alam, 2015, pp. 270-277. URL: https://jurnal.fkip.uns.ac.id/index.php/kpsda/article/vi ew/5386/0

[14] Asmuri, Sarwanto, M. Masykuri, "Pengembangan Modul IPA Terpadu SMP/MTs Kelas VIII Berbasis SETS untuk Meningkatkan Kemampuan Berpikir Kritis", SPEKTRA: Jurnal Kajian Pendidikan Sains 5(1) (2019) 30-43. DOI: 10.32699/spektra.v5vili.84.

[15] I. B. Minarti , S. M. E. S., "Perangkat Pembelajaran IPA Terpadu SETS Berbasis Edutainment Pada Tema Pencernaan", JISE, 1(2) (2012) 105-111. URL: https://journal.unnes.ac.id/sju/index.php/jise/article/vi ew/632

[16] S. Masfuah, A. Rusilowati, Sarwi, "Pembelajaran Kebencanaan Alam Dengan Model Bertukar Pasangan Bervisi Sets Untuk Menumbuhkan Kemampuan Berpikir Kritis Siswa", Jurnal Pendidikan Fisika 
Indonesia $\quad 7(2) \quad(2011) \quad 115-120 \quad$ DOI: 10.15294/jpfi.v7i2.1083.

[17] I. Permatasari, A. Ramdani, A. Syukur, "Pengembangan Bahan Ajar IPA Berbasis Inkuiri Terintegrasi Sets (Science, Environment, Technology And Society) pada Materi Sistem Reproduksi Manusia", J. Pijar Mipa 14(2) (2019) 74-78. DOI: http://dx.doi.org/10.29303/jpm.v14i2.1256

[18] M. K. Nisak, Wartono, H. Suwono, "Pengaruh Pembelajaran Guided Inquiry Berbasis Salingtemas terhadap Keterampilan Berpikir Kritis Siswa SMP berdasarkan Kemampuan Akademik", Jurnal Pendidikan 2(1) (2017) 113-120. DOI: http://dx.doi.org/10.17977/jp.v2i1.8470.

[19] T. Kemdikbud, Panduan Praktis Penyusun e-Modul Pembelajaran, Direktorat Jenderal Pendidikan Dasar dan Menengah Kementerian Pendidikan dan Kebudayaan, 2017.

[20] P. M. Nikita, A. D. Leksmono, A. Harijanto, "Pengembangan e-modul materi fluida dinamis untuk meningkatkan kemampuan berpikir kritis siswa sma kelas xi”, J. Pembelajaran Fis. 7(2) (2018) 175-180. URL:

https://jurnal.unej.ac.id/index.php/JPF/article/downloa d/7925/5581.

[21] H. D. Lestari, D. P. Parmiti, "Pengembangan E-Modul Ipa Bermuatan Tes Online Untuk Meningkatkan Hasil Belajar", Journal of Education Technology 4(1) (2020) 73. DOI: $10.23887 /$ jet.v4i1.24095.

[22] R. Y. Gloria, S. Sudarmin, Wiyanto, D. R. Indriyanti, "The effectiveness of formative assessment with understanding by design (UbD) stages in forming habits of mind in prospective teachers", Journal of Physics: Conf. Series 983(1) (2018). DOI: 10.1088/1742-6596/983/1/012158.

[23] D. F. Sari, M. Fitrianawati, "Pengembangan Media Petualangan Matematika (PETAMATIKA) pada Materi Keliling dan Luas Bangun Datar untuk Kelas IV Sekolah Dasar", Fundamental Pendidikan Dasar 1(1) (2018) 1-13. DOI: https://doi.org/10.12928/fundadikdas.v3i1.1725

[24] Arikunto, Prosedur Penelitian: Suatu Pendekatan Praktek, Rineka Cipta, 2010.

[25] S. D. Sugianto, M. Ahied, W. P. Hadi, A. Y. R. Wulandari, "Pengembangan Modul Ipa Berbasis Proyek Terintegrasi Stem", Journal of Natural Science Education Reseach 1(1) (2018) 28-39. URL: https://journal.trunojoyo.ac.id/nser/article/view/4171

[26] S. Akbar, Instrumen Perangkat Pembelajaran, Remaja Rosdakarya Offset, 2013.

[27] Y. Prasetiyowati, D. Tandyonomanu, "Pengembangan Modul Elektronik pada Mata Pelajaran Animasi 3 Meningkatkan Hasil Belajar di SMK Negeri 1 Magetan", J. Mahasiswa Teknologi Pendidikan 6(2) (2015) $1 . \quad$ URL: https://ejournal.unesa.ac.id/index.php/jmtp/article/vie w/13071

[28] E. Watin, R. Kustijono, Efektivitas Penggunaan Ebook dengan Flip PDF Professional untuk Melatihkan Keterampilan Proses Sains, vol. 1, no. 1, SNF FMIPA UNESA, 2017, pp. 124-129. URL: https://fisika.fmipa.unesa.ac.id/proceedings/index.php /snf/article/view/25.
[29] F. Humairoh, Wasis, "Pengembangan E-Book Interaktif Berbasis Salingtemas (Sains, Lingkungan, Teknologi, Masyarakat) pada Materi Fluida Dinamis untuk Meningkatkan Pemahaman Konsep Siswa dan Penerapannya", JIPF 4(2) (2015) 69-75. DOI: https://doi.org/10.26740/ipf.v4n2.p\%25p

[30] N. Afrianis, A. Binadja, E. Susilaningsih, "Peningkatan Ketrampilan Berpikir Kritis Siswa Dengan Menggunakan Model Inkuiri Terbimbing Bervisi SETS," Konfigurasi 1(2) (2017) 203-210. DOI:

http://dx.doi.org/10.24014/konfigurasi.v1i2.4316

[31] Juhji, "Model Pembelajaran Sains Teknologi Masyarakat dalam Pembelajaran IPA", Primary 08(2) (2016) 25-34. URL: http://jurnal.uinbanten.ac.id/index.php/primary/article /view/144

[32] Y. F. Narut, K. Supradi, "Literasi sains peserta didik dalam pembelajaran ipa di indonesia", JIPD 3(1) (2019) 61-69. URL: http://jurnal.unikastpaulus.ac.id/ind ex.php/jipd/article/ view/214

[33] P. A. Facione, "Critical Thinking: What It Is and Why It Counts diakses," (https://www.insightassessment.com/wpcontent/uploads/ia/pdf/whatwhy.pdf), 2020.

[34] J. Low, M. Shahrill, J. S. H. Q. Perera, R. C. I. Prahmana, "Characterising formative assessment practices in the mathematics classes", Journal of Physics: Conf. Series 1088 (2018). DOI: 10.1088/1742-6596/1088/1/012015.

[35] N. Deswari, D. Supardan, "Upaya Peningkatan Environmental Literacy Peserta Didik Di Sekolah Adiwiyata (Studi Inkuiri Naturalistik Di Sd Negri 138 Pekanbaru)", Jurnal Socius 5(2) (2016). DOI: 10.20527/jurnalsocius.v5i2.3331.

[36] E. Winarsih, Y. Furinawati, Literasi Teknologi Dan Literasi Digital Untuk Menumbuhkan Keterampilan Berwirausaha Bagi Kelompok Pemuda Di Kota Madiun, vol. 1, no. 1, Pros. Semin. Nas. Int., 2018, pp. 23-29.

URL: https://jurnal.unimus.ac.id/index.php/psn12012010/art icle/view/4181

[37] B. Tejokusumo, "Dinamika Masyarakat Sebagai Sumber Belajar Ilmu Pengetahuan Sosial”, Geoedukasi 3(1) (2014) 38-43. URL: http://www.jurnalnasional.ump.ac.id/index.php/GeoE dukasi/article/view/588/581

[38] D. Desyandri, M. Muhammadi, M. Mansurdin, and R. Fahmi, "Development of integrated thematic teaching material used discovery learning model in grade $\mathrm{V}$ elementary school", Jurnal Konseling dan Pendidikan 7(1) (2019) 16. DOI: 10.29210/129400.

[39] I. Laili, Ganefri, Usmeldi, "Efektivitas Pengembangan E-Modul Project Based Learning Pada Mata Pelajaran Instalasi”, J. Imiah Pendidik. dan Pembelajaran 3 (2019) 306-315. URL: https://ejournal.undiksha.ac.id/index.php/JIPP/article/ download/21840/13513.

[40] S. Kusairi, "Buku Asesment Pembelajaran Sains," FMIPA UM, 2013 